\title{
Flow cytometric DNA content analysis of neoplastic cells in haemolymph of the cockle Cerastoderma edule
}

\author{
Patricia Mirella da Silva ${ }^{1}$, Philippe Soudant ${ }^{2}$, Maria Jesús Carballal ${ }^{1, *}$, \\ Christophe Lambert ${ }^{2}$, Antonio Villalba ${ }^{1}$ \\ ${ }^{1}$ Centro de Investigacións Mariñas, Consellería de Pesca e Asuntos Marítimos, Xunta de Galicia, Aptdo. 13, \\ 36620 Vilanova de Arousa, Spain \\ ${ }^{2}$ LEMAR/IUEM/UBO, UMR 6539, Technopole Brest-Iroise, Place Nicolas Copernic, 29280 Plouzané, France
}

\begin{abstract}
Epizootiological outbreaks of disseminated neoplasia (DN) have been reported in association with mass mortalities in various bivalve species including the cockle Cerastoderma edule. A flow cytometric (FCM) procedure to study DNA content was successfully adapted and tested in haemolymph cells (haemocytes and neoplastic cells) of the cockle. The FCM results were similar to those obtained by histological analysis (DN diagnosis and haemolymph cell features). FCM analysis revealed differences in DNA content among normal haemocytes (diploid) and neoplastic cells. Four types of cells with abnormal DNA content were found in the haemolymph of affected animals: hypodiploid, hyperdiploid, triploid-sesploid and pentaploid. Our results suggest that the flow cytometric DNA content analysis can be applied to identify neoplastic cell types and to study the association between different cell types and the DN progression or remission in this edible and commercially important bivalve species.
\end{abstract}

KEY WORDS: Flow cytometry $\cdot$ DNA content $\cdot$ Disseminated neoplasia $\cdot$ Cerastoderma edule $\cdot$ Bivalve

\section{INTRODUCTION}

Flow cytometric (FCM) analyses have been extensively used in humans, providing valuable information in the diagnosis, classification and prognosis of a variety of diseases (Ward 1999, O'Gorman \& Scholl 2002). The flow cytometer is able to rapidly screen large numbers of cells far beyond the capacity of traditional pathological or cytological methods, which makes it attractive to use in bivalve models. FCM analysis was used in earlier studies of bivalves, in attempts to separate and define haemocyte populations, and was ultimately extended to examine bivalve immunology and pathology (see review by Ashton-Alcox et al. 2001). Its effectiveness has been demonstrated in recent reports (Allam et al. 2002a,b, Soares-da-Silva et al. 2002, Hégaret et al. 2003a,b, Lambert et al. 2003, 2004, Soudant et al. 2004). DNA content and cell cycle measurement was one of the earliest applications of flow cytometry (Valet 2003, Darzynkiewicz et al. 2004). Measuring the DNA content in cells by FCM permits characterisation of cells in the $G_{0} / G_{1}, S$ and $G_{2} / M$ phases of the cell cycle and also detection of populations of cells that have abnormal amounts of DNA (polyploid or aneuploid). Disseminated neoplasia (DN) is a pathological condition that has been reported in association with mass mortalities of various bivalve species (Elston et al. 1992), including the cockle Cerastoderma edule (Twomey \& Mulcahy 1984). In Galicia (NW Spain) Carballal et al. (2001) described the prevalence of DN in several natural beds of $C$. edule, and Villalba et al. (2001) reported high mortalities in natural populations of $C$. edule associated with high prevalence and severity of DN. To date, the former authors have identified to some extent 2 types of neoplastic cells in the tissues of C. edule in Galicia (Carballal et al. 2001). FCM ana- 
lysis can provide a fast and accurate way to measure DNA content and establish the ploidy level in neoplastic cells (Elston et al. 1990, Moore et al. 1991, Reno et al. 1994) and, thus, promote a more comprehensive study of DN in the cockle $C$. edule. The present work aimed to optimise and validate the procedure used to measure DNA content by FCM analysis of normal and neoplastic cells of C. edule (Collins 1998) and to compare the results obtained with histological methods based on optical microscopy.

\section{MATERIALS AND METHODS}

Animals. In January and February 2004, cockles (Cerastoderma edule: Mollusca: Bivalvia) from natural populations affected by DN were collected from the Ría de Noia $(\mathrm{N}=30)$ and the Ría de Arousa $(\mathrm{N}=20)$ (Galicia, NW Spain), and 30 cockles were collected from a DN-free population in the north of Finistère (Brittany, France). The cockles were kept in tanks with flowing raw seawater for no more than $3 \mathrm{~d}$.

Sampling and histological preparations. Haemolymph was extracted from all (80) cockles. The cockle shell was notched just above the adductor muscle, and haemolymph was withdrawn using a 21 gauge needle attached to a $2 \mathrm{ml}$ syringe. Haemolymph was then transferred into microtubes and maintained on ice to prevent clumping. A drop of haemolymph from each individual was observed under an optical microscopy, and individuals carrying large cells (presumed neoplastic) were selected for the next procedure $(\mathrm{N}=11)$. Normal cockles, with normal haemocyte size, were also selected (30 from France and 4 from Galicia). The haemolymph of selected cockles was used both to perform FCM analysis and to make haemolymph cell monolayers (HCM). For each of these individuals, a piece of tissue ( $5 \mathrm{~mm}$ thick) containing the visceral mass, foot, mantle lobes and gills was excised to generate histological sections (HS). HCM and HS analyses were not performed on cockles from France. The HCM and HS procedures were performed according to da Silva \& Villalba (2004), and the HSs were used to diagnose DN (except one, for which a HS was not obtained and the diagnosis of DN was based on HCM). The intensity of DN was rated according to the following scale-light: small number of neoplastic cells in blood vessels and connective tissue of gills, surrounding gonad and digestive tract; moderate: various and small foci of neoplastic cells that have infiltrated the connective tissue of all organs; and heavy: large and numerous foci of neoplastic cells that have infiltrated the connective tissue of all organs. The diameter of the neoplastic cell and of the nucleus were measured $(\mathrm{N}=15)$ in HS, and the nucleus:cytoplasm ratio was obtained by analysis of HCM.
Flow cytometry analysis. One volume of haemolymph of individual cockles was re-suspended gently and dropped into a centrifuge tube containing $4 \mathrm{vol}$ of ethanol $100 \%$ (final concentration $80 \%$ ), previously cooled at $-20^{\circ} \mathrm{C}$ while vortexing at high speed. Some precipitation of the serum proteins occurred during this procedure; these were removed by subsequent washes. The samples were then stored at $-20^{\circ} \mathrm{C}$ for 1 mo until further use. Fixed haemolymph was centrifuged $\left(400 \times g\right.$ for $10 \mathrm{~min}$ at $\left.4^{\circ} \mathrm{C}\right)$, and the ethanol was decanted. The pellet was gently re-suspended (using a pipette) in $0.01 \mathrm{M}$ phosphate buffer saline (PBS, with $2 \% \mathrm{NaCl}_{1} \mathrm{pH} 7.4$ ) at room temperature; PBS 0.1 M was also tested. The cell suspension was allowed to re-hydrate for $30 \mathrm{~min}$, followed by 2 washes in PBS and centrifugation $\left(400 \times g\right.$ for $10 \mathrm{~min}$ at $\left.20^{\circ} \mathrm{C}\right)$. Finally, the pellet was re-suspended in PBS and transferred into a flow cytometer tube by filtering through an $80 \mu \mathrm{m}$ mesh sieve. After addition of propidium iodide (PI, Sigma, P4170) $\left(50 \mu \mathrm{g} \mathrm{ml}^{-1}\right)$ and DNase-free RNase A (Sigma, R4875) $\left(50 \mathrm{\mu g} \mathrm{ml}^{-1}\right)$, the samples were incubated at room temperature in the dark for $60 \mathrm{~min}$, a time previously established as optimal for PI staining. PI staining was observed to be stable after $30 \mathrm{~min}$ and until 120 min.

Measurement of DNA content of haemolymph cells of cockle. The developed FCM protocol was based on the properties of PI $\left(\lambda_{\text {ex }}=536 \mathrm{~nm}, \lambda_{\text {em }}=617 \mathrm{~nm}\right)$, which stains by intercalating into nucleic acid molecules (both DNA and RNA). When PI binds to DNA its fluorescence intensity is proportional to the DNA cell content, thus allowing the study of cell ploidy by FCM (Krishan 1975). Since PI can also bind to doublestranded RNA, it was necessary, as described above, to treat the cells with RNase to eliminate the RNA chains for optimal DNA resolution.

The samples were analysed using a FACSCalibur flow cytometer (Becton Dickinson), equipped with an air-cooled laser providing $15 \mathrm{~mW}$ at a wavelength of $488 \mathrm{~nm}$. For each sample, 10000 particles were counted at a low flow rate $\left(15 \mu \mathrm{min}^{-1}\right)$. PI fluorescence was detected on the FL2 detector (orange-red light, 564 to $606 \mathrm{~nm}$ ) and used as the discriminating factor to collect multiparametric data on individual events (cell). For each individual event (cell), the instrument provided a single electronic pulse of PI fluorescence. This pulse can be described according to its area, width and height (Fig. 1). Pulse area was used to provide a measurement of DNA content. In order to distinguish cells in the $G_{2} / M$ phase from doublets of $G_{0} / G_{1}$ cells (2 cells stuck together) that have the same DNA content ( $4 \mathrm{n}$ or $2 n+2 n$, respectively), it is necessary to compare the pulse width or height (Fig. 1) with the pulse area. In the present study, the FL2-area vs. FL2-width dot-plot was used to gate single cells (Fig. 2A). To discriminate 

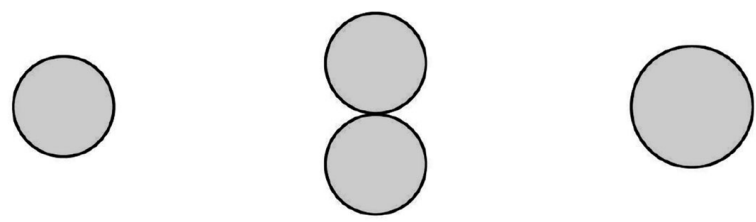

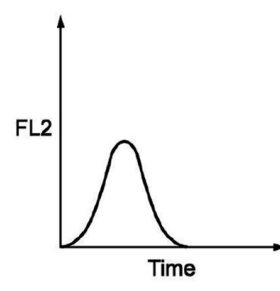

G0 / G1

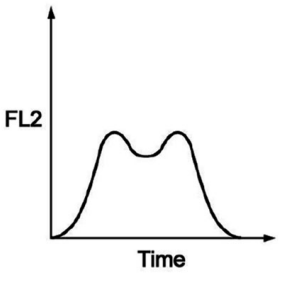

G1 Doublet

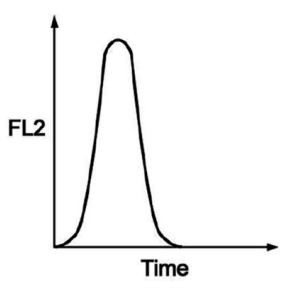

G2 / M
Fig. 1. FL2 height vs. time, showing different pulse heights and pulse widths according to the type of event: (A) when 1 cell passes alone, (B) when 2 cells pass together and (C) when 1 cell in $\mathrm{G}_{2} / \mathrm{M}$ passes alone. FL2 height or FL2 width vs. FL2 area permits discrimination of doublet from single cells

single cells from doublets, a region (R1) was drawn on this dot-plot representation (Fig. 2A). Doublets can be seen on the right of R1. After gating them on R1, single cells were next plotted on a FL2 histogram (Fig. 2B) and used to calculate the percentages of cell populations according to their DNA content.

Although changes in the number or composition of individual chromosomes were not measured directly, cytogenetic terminology (hypodiploid, hyperdiploid, triploid, tetraploid, pentaploid) was used. The DNA index (DI), which is used to derive a quantitative estimate of the relative DNA content between the test cell and diploid cell, was calculated as the ratio between the mode of the relative DNA content of the neoplastic cells (in $\mathrm{G}_{0} / \mathrm{G}_{1}$ phase) and the mode of the relative DNA content in normal $\mathrm{G}_{0} / \mathrm{G}_{1}$ diploid cells. Additionally, granularity and size characteristics of single cells can be assessed using the side- and forward-scatter parameters (SSC and FSC), respectively, after gating them on R1, of their FL2-width vs. FL2-area dot-plots.

\section{RESULTS AND DISCUSSION}

A FCM protocol was successfully established, by adapting the protocol previously described (Collins 1998), to quantify DNA content in haemolymph cells of Cerastoderma edule and was applied to diagnostic haemolymph neoplastic cells according to their ploidy levels. Our study led to several optimisation steps. It was preferable to fix the cells in a more concentrated ethanol solution (80\%) than that used by Collins (1998) $(70 \%)$. Furthermore, during the washing procedure, a PBS concentration of $0.01 \mathrm{M}$ (instead of $0.1 \mathrm{M}$ ) at room temperature (not cold PBS) (results not shown) was optimal in maintaining discrete samples and preventing cell aggregation. These conditions were not specified by Collins (1998).

The results of histological analysis showed that 10 of 15 cockles from Spain showed DN with light (4), moderate (3) and heavy (3) intensity. The condition of 5 individuals previously identified as normal was confirmed on HS and HCM. During the procedures for FCM analysis, 4 haemolymph samples of neoplastic cockles were lost, due to the low volume used to allow replication of the same individual or during the washing steps. The haemolymph of the remaining 6 neoplastic cockles showed abnormal DNA content. One of the samples with light DN was hypodiploid (the presence of an abnormal peak below the diploid peak), and its DI was 0.94. One with light DN was hyperdiploid (the presence of an abnormal peak above the diploid peak), and its DI was 1.05. The cockles with moderate or heavy DN were pentaploid (5n) or triploid (3n), and their DIs were 2.3 and 1.6, respectively. The results are
Fig. 2. Cerastoderma edule. Flow cytometry of normal haemocytes from the cockle. (A) The majority of single cells (Region R1) are diploid ( $2 \mathrm{n}, \mathrm{G}_{0} / \mathrm{G}_{1}$ phase), with few cells having fully replicated DNA ( $4 \mathrm{n}, \mathrm{G}_{2} / \mathrm{M}$ phase). Doublets and other higher associations are represented on the right of $\mathrm{R} 1$. (B) After gating on R1, peaks represent the distribution of the single-cell populations according to their DNA content. Their respective proportions were estimated using histogram markers. Markers 1 (M1) and 2 (M2) delimited, respectively, $\mathrm{G}_{0} / \mathrm{G}_{1}$ and $\mathrm{G}_{2} / \mathrm{M}$ cells
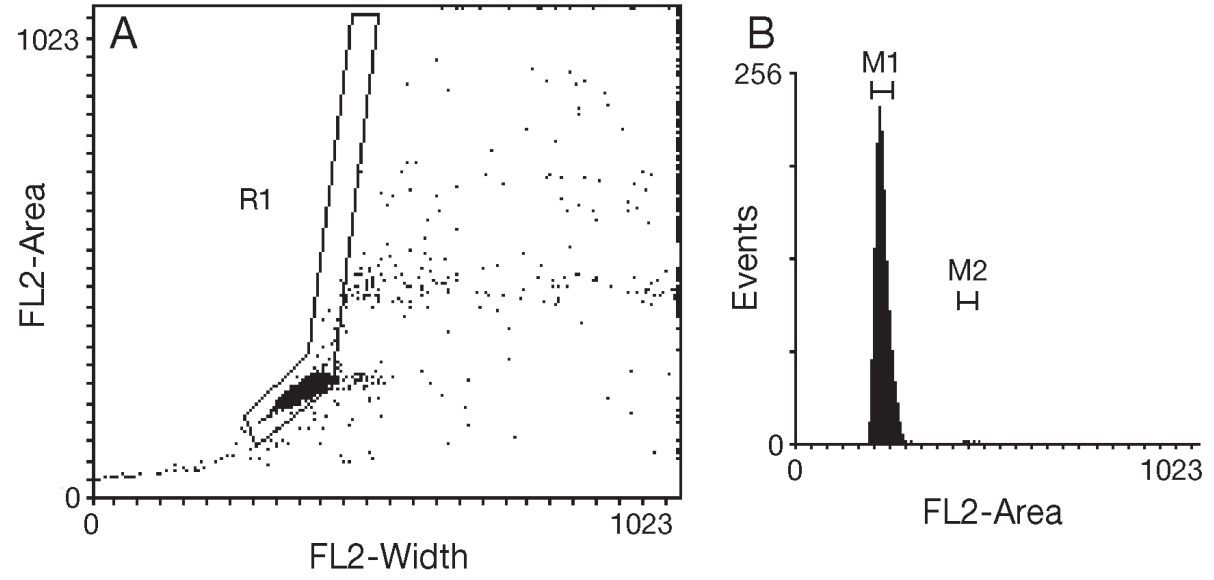
Table 1. Cerastoderma edule. Class of ploidy and DNA index (DI) ( \pm SD) obtained by flow cytometric (FCM) analysis for cockles diagnosed for disseminated neoplasia (DN) using haemolymph cell monolayers and histological section. Cockles originated from the Ría de Noya and the Ría de Arousa (Galicia, NW Spain) (G) and from north of Finistère (Brittany, France) (F) (N, number of cases; *individuals lost during sample preparation for FCM analysis; ${ }^{* *}$ by definition a DNA diploid specimen has a DNA index of 1.0)

\begin{tabular}{|c|c|c|c|c|c|}
\hline Source & Diagnostic & DN rating & DI & Ploidy level & $\mathrm{N}$ \\
\hline G & Neoplasia & Null and light & $0.94 \pm 0.0$ & Hypodiploid & 2 \\
\hline $\mathrm{G}$ & Neoplasia & Light & 1.05 & Hyperdiploid & 1 \\
\hline G & Neoplasia & Heavy (both) & $1.6 \pm 0.0$ to $3.1 \pm 0.0$ & Triploid-Sesploid & 2 \\
\hline $\mathrm{G}$ & Neoplasia & Moderate and heavy & $2.3 \pm 0.0$ & Pentaploid & 2 \\
\hline G & Normal & Null & 1.0 & Diploid** & 4 \\
\hline G & Neoplasia & Moderate and light & $*$ & $*^{*}+$ & 4 \\
\hline $\mathrm{F}$ & Normal & Not done & 1.0 & Diploid $^{* *}$ & 30 \\
\hline
\end{tabular}

summarised in Table 1. In contrast, 4 out of 5 normal cockles from Galicia presented normal diploid DNA contents $(2 n)$, which were identical to those measured in the 30 cockles originating from France (data not shown). This suggested that if DN occurs in cockles from north of Finistère (Brittany), France, as observed by Poder \& Auffret (1986), it should be at low prevalence. One individual detected as normal by HCM and HS was found to be hypodiploid by FCM (Table 1). Collins (1998) studied DN in Cerastoderma edule from Ireland and also found all the types of ploidy described here. Moreover, Collins found tetraploid individuals,
A

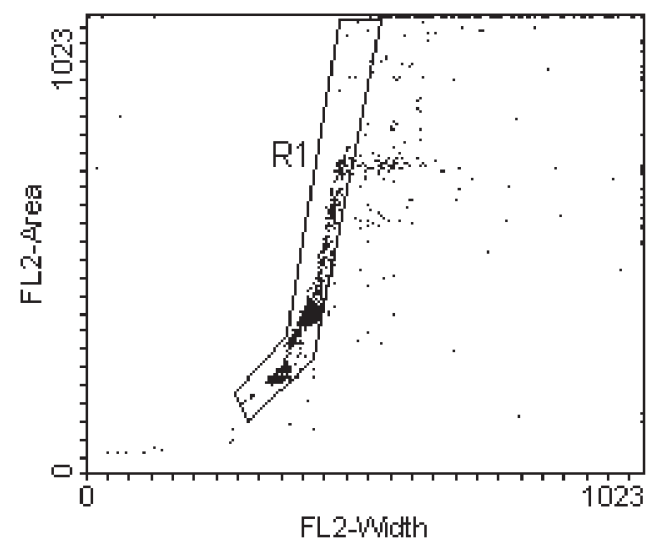

C

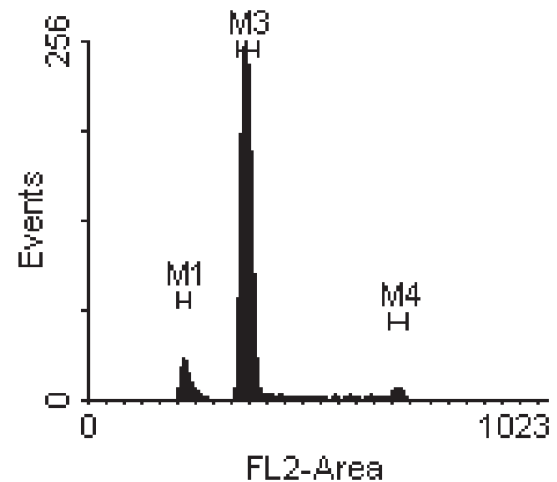

B
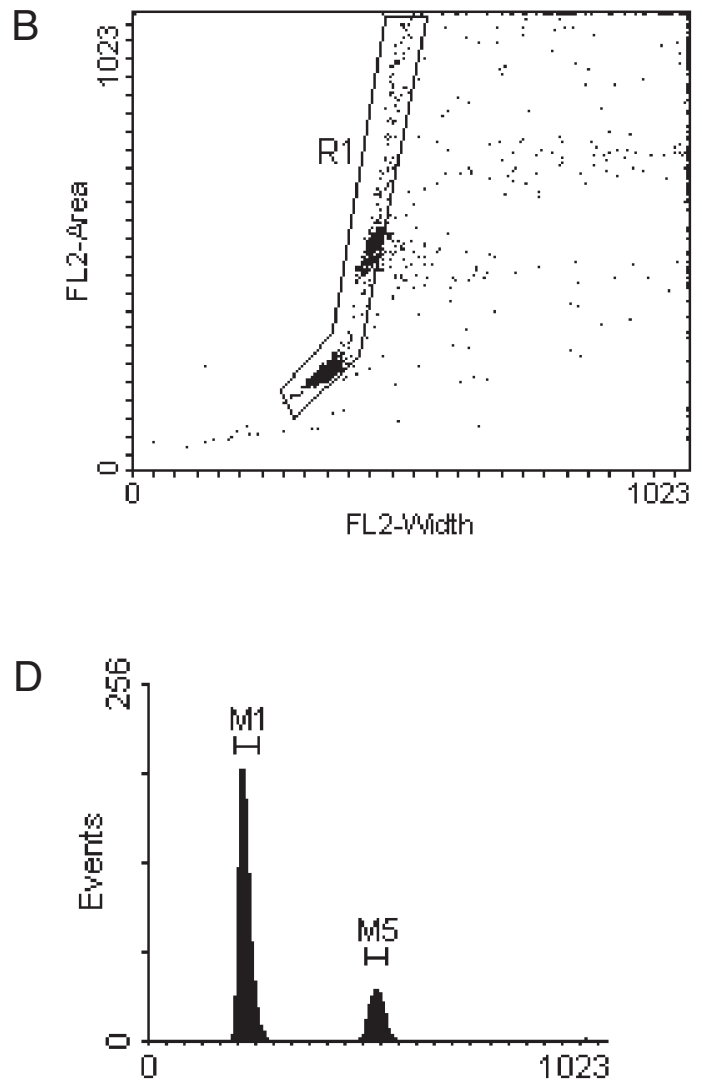

FL2-Ariea

Fig. 3. Cerastoderma edule. FL2-width vs. FL2-area (linear scales) dot-plots and FL2-area histograms of cockle neoplastic cells, from triploid-sesploid specimens (A and C) and pentaploid specimens (B and D). (A, B) Region R1 contains the cell population to be analysed. (C, D) After R1 gating, the peaks represent the distributions of the cell populations according to DNA content. The proportions of each cell population were estimated using histogram markers. Markers 1 (M1) delimited the diploid (2n) peak in neoplastic cells. Markers 3, 4 and 5 delimited aneuploid peaks: triploid (3n), sesploid (6n) and pentaploid (5n), respectively 
not observed in the present study, probably because of the low number of cockles we analysed. However, the numbers of tetraploid individuals were low, and the most frequent type was pentaploid (Collins 1998). In neoplastic mussels (Mytilus edulis) 2 groups of individuals with abnormal DNA content were found, one being tetraploid and the other pentaploid, although both forms could occur simultaneously in the same individual, but this was less common (Moore et al. 1991). In contrast, Mya arenaria affected by DN did not exhibit pentaploid cells, but a single population of hypotetraploid cells (Reno et al. 1994).

The DNA histogram obtained by FCM analysis of a normal cockle was dominated by a large peak representing the DNA content of diploid (2n) cells $\left(\mathrm{G}_{0} / \mathrm{G}_{1}\right.$ phase) and a small peak with a few tetraploid cells $\left(\mathrm{G}_{2} / \mathrm{M}\right.$ phase) (Fig. 2B). In neoplastic cells the DNA content varied from these values, resulting in other peaks at different horizontal ( $X$-axis) positions on the DNA histogram (Fig. 3C,D). Fig. 3A,C shows 1 neoplastic cell type from cockles, predominated by triploid $(3 n)$ cells along with smaller diploid $(2 n)$ and sesploid (6n) peaks. Sesploid cells are thought to correspond to triploid neoplastic cells in the $\mathrm{G}_{2} / \mathrm{M}$ phase. Another neoplastic cell type is represented in Fig. 3B,D; it shows a diploid peak accompanied by a small pentaploid (5n) peak.

SSCs and FSCs are represented in 2-dimensional density plots and were used to distinguish cell populations according to their granularity (SCC) and size (FSC). Normal cells were observed to have large (broad) size and complexity distributions (Fig. 4A). This is likely to reflect the existence of 4 haemocyte types as described by Wootton et al. (2003): 2 types of granulocytes (eosinophils and basophils), small hyalinocytes and another type of eosinophil, with a very large vacuole only described in cockles and called Type III. In neoplastic animals, cells with DNA content of $3 n$ and $6 n$, thought to be the $G_{2} / M$ phase of $3 n$, constituted a single group showing (Fig. 4B) a greater size and complexity than the diploid cells found in normal cockles. Though sesploid cells were difficult to separate from the triploid cells, they tended to have a higher complexity than $3 \mathrm{n}$ cells. On the other hand, pentaploid cells were clearly larger and more complex than the

Fig. 4. Cerastoderma edule. Forward-scatter (FSC, size) vs. side-scatter (SSC, granularity) density plots of cockle haemolymph cells. The single-cell population was gated on the FL2-width vs. FL2-area dot-plots. (A) Normal cockle: the main cell population was constituted by diploid $(2 \mathrm{n})$ cells. (B) Neoplastic cockle containing diploid cells (R1) and triploid cells as the main population (R2), as well as sesploid cells (arrowhead) that are included in the triploid group. (C) Another type of neoplastic cells containing pentaploid cells (R2), but also diploid (R1)
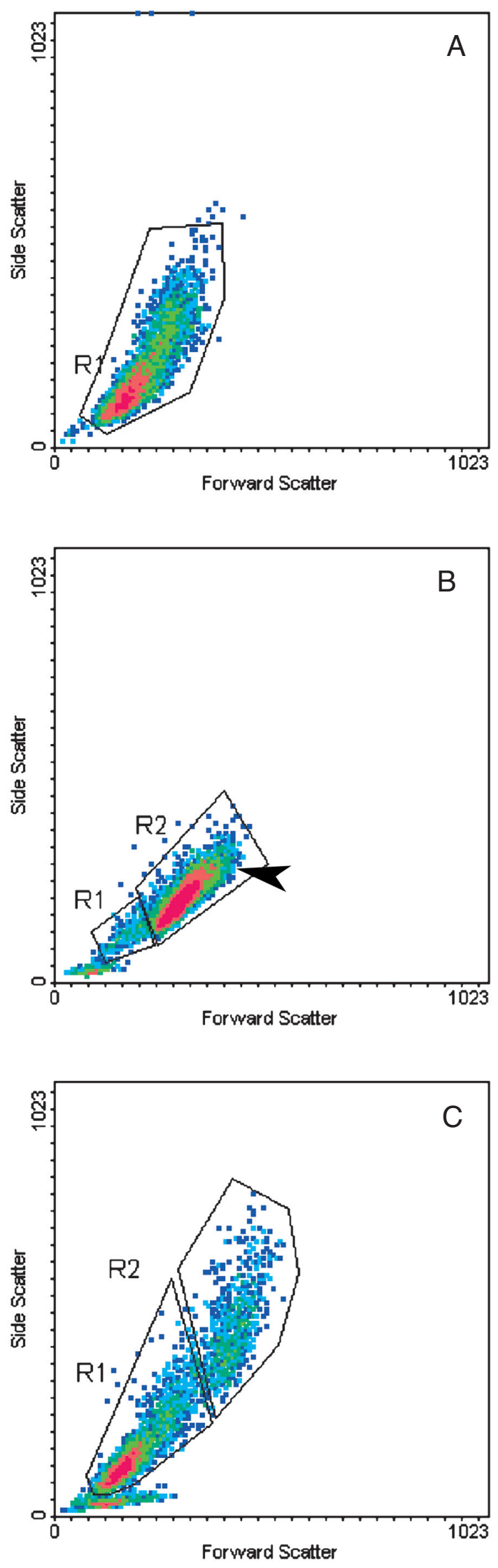
others ( $2 n$ and $3 n)$, as shown by the location of the R2 region in Fig. 4C. Lowe \& Moore (1978) provided evidence for a correlation between DNA content and the size of neoplastic cells in Mytilus edulis. In the case of hyperdiploid and hypodiploid cells, they could not be distinguished from normal diploid cells by the SSC or FSC parameters. Interestingly, a comparison of the FSC and SSC parameter results obtained by FCM analysis with those obtained by microscopic analysis showed very good agreement between these techniques. Triploid cells were larger $(7.3 \pm 0.2 \mu \mathrm{m}-$ data for 1 animal, the HS of the other triploid was not obtained) than normal $(6.0 \pm 0.14 \mu \mathrm{m})$, but smaller than pentaploids $(9.9 \pm 0.2 \mu \mathrm{m})$. Hyperdiploid cells were slightly smaller $(5.9 \pm 0.2 \mu \mathrm{m})$ than normal cells, but the nucleus:cytoplasm ratio was higher $(0.73 \pm 0.05)$ than in normal diploid cells $(0.67 \pm 0.05)$. This could mean that the DNA content was also higher than in normal diploid cells, which is in agreement with FCM analysis. The results of hypodiploid cells were not consistent, since there were differences within hypodiploid cases; in one, which was detected as normal by HS and HCM, the cells were smaller $(5.9 \pm 0.3 \mu \mathrm{m})$, which was in agreement with FCM results, but in the second one, the neoplastic cells were larger $(11.8 \pm 0.3 \mu \mathrm{m})$ than normal diploid cells. The latter case might be explained by the fact that most cells found in haemolymph were hypodiploid, as measured by FCM, and may not correspond to the few cells measured in HS, which showed a large mean size. In other words, hypodiploid cells detected by FCM may not be detectable by HS. Hypodiploid and hyperdiploid cells might represent an initial stage of neoplasia in the haemolymph of cockles, as all cases corresponded to animals holding light-disseminated neoplasia, as suggested by Collins (1998). To improve our understanding concerning the ploidy level and DN in cockles, more individuals should be analysed by FCM, which would strengthen the results obtained here.

Flow cytometric analysis using the procedure optimised and established here allowed us to quantify satisfactorily the DNA content in Cerastoderma edule. Furthermore, it was successfully applied to both normal haemocytes and neoplastic cells of the cockle haemolymph. Preliminary results showed that major changes in DNA content can occur in neoplastic cells, and at least 4 types of abnormal DNA content could be diagnosed. Flow cytometry has been demonstrated for other bivalve species to be a useful technique in the diagnosis of ploidy; FCM is useful in predicting neoplasia types (Moore et al. 1991) and in studying its proliferation (Elston et al. 1990). Thus, this technique could be useful in further work on the different types of neoplastic cells in C. edule, their influence on disease proliferation, as well as their impact on the host.
Acknowledgements. P.M.daS. was supported by a scholarship from the 'Conselho Nacional de Desenvolvimento Científico e Tecnológico' (CNPq) of the Brazilian Government.

\section{LITERATURE CITED}

Allam B, Ashton-Alcox KA, Ford SE (2002a) Flow cytometric comparison of haemocytes from three species of bivalve molluscs. Fish Shellfish Immunol 13:141-158

Allam B, Ashton-Alcox KA, Ford SE (2002b) Flow cytometric measurement of hemocyte viability and phagocytic activity in the clam, Ruditapes philippinarum. J Shellfish Res 21:13-19

Ashton-Alcox KA, Allam B, Ford SE (2001) Application of flow cytometry to bivalve pathology. In: Fingerman M, Nagabhushanam R (eds) Recent advances in marine biotechnology, Vol 5. Science Publishers, Plymouth, p 85-124

Carballal MJ, Iglesias D, Santamarina J, Ferro-Soto B, Villalba A (2001) Parasites and pathologic conditions of the cockle Cerastoderma edule populations of the coast of Galicia (NW Spain). J Invertebr Pathol 78:87-97

Collins C (1998) Studies on a neoplasm of the cockle Cerastoderma edule (Linnaeus). PhD dissertation, National University of Ireland, Cork

Darzynkiewicz Z, Crissman H, Jacobberger JW (2004) Cytometry of the cell cycle: through history. Cytometry 58A: 21-32

da Silva PM, Villalba A (2004) Comparison of light microscopic techniques for the diagnosis of the infection of the European flat oyster Ostrea edulis by the protozoan Bonamia ostreae. J Invertebr Pathol 85:97-104

Elston RA, Drum AS, Allen SK (1990) Progressive development of circulating polyploid cells in Mytilus with hemic neoplasia. Dis Aquat Org 8:51-59

Elston RA, Moore JD, Brooks K (1992) Disseminated neoplasia of bivalve mollusc. Rev Aquat Sci 6:405-466

Hégaret H, Wikfors GH, Soudant P (2003a) Flow-cytometric analysis of haemocytes from eastern oysters, Crassostrea virginica, subjected to a sudden temperature elevation. I. Haemocyte types and morphology. J Exp Mar Biol Ecol 293:237-248

Hégaret H, Wikfors GH, Soudant P (2003b) Flow-cytometric analysis of haemocytes from eastern oysters, Crassostrea virginica, subjected to a sudden temperature elevation. II. Haemocyte functions: aggregation, viability, phagocytosis, and respiratory burst. J Exp Mar Biol Ecol 293:249-265

Hégaret $\mathrm{H}$, Wikfors $\mathrm{GH}$, Soudant $\mathrm{P}$, Delaporte $\mathrm{M}$ and 8 others (2004) Immunological competence of eastern oysters, Crassostrea virginica, fed different microalgal diets and challenged with a temperature elevation. Aquaculture 234:541-560

Krishan A (1975) Rapid cytofluorometric analysis of mammalian cell cycle by propidium iodide staining. J Cell Biol 66:188-193

Lambert C, Soudant P, Choquet G, Paillard C (2003) Measurement of Crassostrea gigas haemocyte oxidative metabolism by flow cytometry and the inhibitin capacity of pathogenic vibrios. Fish Shellfish Immunol 15:225-240

Lowe DM, Moore MN (1978) Cytology and quantitative cytochemistry of a proliferative atypical haemocytic condition in Mytilus edulis (Bivalvia: Mollusca). J Natl Cancer Inst 60:1455-1459

Moore JD, Elston RA, Drum AS, Wilkinson MT (1991) Alternate pathogenesis of systemic neoplasia in the bivalve mollusc Mytilus. J Invertebr Pathol 58:231-243

O'Gorman MRG, Scholl PR (2002) Role of flow cytometry in 
the diagnostic evaluation of primary immunodeficiency disease. Clin Appl Immunol Rev 2:321-335

Poder M, Auffret M (1986) Sarcomatous lesion in the cockle Cerastoderma edule. I. Morphology and population survey in Brittany, France. Aquaculture 58:1-8

Reno PW, House M, Illingworth A (1994) Flow cytometric and chromosome analysis of softshell clams, Mya arenaria, with disseminated neoplasia. J Invertebr Pathol 64:163-172

Soares-da-Silva IM, Ribeiro J, Valongo C, Pinto R, Vil M, Bleher R, Machado J (2002) Cytometric, morphologic and enzymatic characterisation of haemocytes in Anadonta cygnea. Comp Biochem Physiol 132:541-553

Soudant P, Paillard C, Choquet G, Lambert C, Reid HI, Marhic A, Donaghy L, Birbeck TH (2004) Impact of season and rearing site on the physiological and immunological parameters of the Manila clam Venerupis $(=$ Tapes,$=$ Ruditapes) philippinarum. Aquaculture 229:401-418

Editorial responsibility: Albert Sparks, Seattle, Washington, USA
Twomey E, Mulcahy MF (1984) A proliferative disorder of possible haemic origin in the common cockle, Cerastoderma edule. J Invertebr Pathol 44:109-111

Valet G (2003) Past and present concepts in flow cytometry: a European perspective. J Biol Reg Homeos Ag 17:213-222

Villalba A, Carballal MJ, López C (2001) Disseminated neoplasia and large foci indicating heavy haemocytic infiltration in cockles (Cerastoderma edule) from Galicia (NW Spain). Dis Aquat Org 46:213-216

Ward MS (1999) The use of flow cytometry in the diagnosis and monitoring of malignant hematological disorders. Pathology 31:382-392

Wootton EC, Dyrynda EA, Ratcliffe NA (2003) Bivalve immunity: comparisons between the marine mussel (Mytilus edulis), the edible cockle (Cerastoderma edule) and the razor-shell (Ensis siliqua). Fish Shellfish Immunol 15: $195-210$

Submitted: January 8, 2005; Accepted: July 8, 2005

Proofs received from author(s): October 21, 2005 